\title{
Status of Federal Income and Estate Taxes on Community Property in California
}

\footnotetext{
THE subject of community property is of unusual interest at present in connection with United States income and estate taxes.
}

In Treasury Decisions 3071 it was held, pursuant to the opinion of Attorney-General A. Mitchell Palmer, that in Texas the husband and wife domiciled therein could render separate income-tax returns and each report as gross income one-half of the community income.

In Treasury Decision 3138, pursuant to a further opinion of Attorney-General Palmer, the same ruling was made as to Arizona, Idaho, Louisiana, Nevada, New Mexico and Washington. It was further held that in those states in computing Federal estate tax of a deceased spouse there should be included in the gross estate onehalf only of the community property of husband and wife domiciled therein.

Under these two rulings, spouses with a large community income, by each rendering an income tax return in which is reported onehalf thereof, are enabled to save some of the surtax which, with its graduated rates, would, of course, amount to more on one income of $\$ 100,000$, for example, than on two incomes of $\$ 50,000$ each. The saving as regards the estate tax is self-explanatory also.

California, the only other of our states having a community property system, was purposely excluded from the benefit of Treasury Decision 3138. The Attorney-General in his opinion analyzed the community property laws of each of the states involved, including California. He pointed out that except in California it had always been held by the court of the state in question that the wife had, during the existence of the marriage relation, a vested interest in one-half of the community property ; that, on the other hand, in California it had always been held that the wife had no vested interest in the community property, but that her right therein was

1 Scott v. Scott (1914) 170 S. W. 273; (Tex. Civ. App.); Holyoke v. Jackson (1882) 3 Wash. Ter. 235, 3 Pac. 841; Warburton v. White (1900) 176 U. S. 484, 44 L. Ed. 555, 20 Sup. Ct. Rep. 404; In re William's Estate (1916) 40 Nev. 241, 161 Pac. 741; Beales v. Ares (1919) 25 N. Mex. 459, 185 Pac. 780; Arnett v. Reade (1911) 220 U. S. 311, 55 L. Ed. 477, 31 Sup. Ct. Rep. 442; La Tourette v. La Tourette (1914) 15 Ariz. 200, 137 Pac. 426; Kohny v. Dunbar (1912) 21 Idaho, 258, 121 Pac. 544, 39 L. R. A. (N. S.) 1107; Am. Cas. 1913D 492; Succession of Marshal (1907) 118 La. 211, I12 So. 778; Beck v. Natalie Oil Co. (1918) 143 La. 154, 78 So. 430. 
in the nature of a mere expectancy, like that of an heir. ${ }^{2}$ It was because of this difference that California was not included in the ruling, and from the point of view of strict theory or logic, no fault can be found with this result, assuming that the Federal government in applying taxation statutes of its own to community property should follow the law of the state as to the nature of the interests held by the husband and wife respectively in such community property.

One cannot help feeling, though, that the result is unfair, is opposed to the practical side of the matter, and rests on what the early judges in California said in describing the wife's interest many years ago, at a time when a Federal income tax like the present one was unthought of. ${ }^{3}$ The point is that now at least there is no real basis or foundation for a distinction between the nature of the wife's interest in the community property in California and in all the other community property states. Naturally, to see if such distinction is justified, one turns to the relative powers and rights possessed by the husband and by the wife in the various community property states. When this is done (taking into account Section 172a of the Civil Code, added in 1917) ${ }^{4}$ it will be found that the rights of the husband are no greater and those of the wife no less in California than in any other community property state. Thus, in all the states the husband is given the management of the community personalty, and may transfer it for a valuable consideration without the wife's consent. $^{5}$

In all the states the husband is given the management of the community real property, ${ }^{6}$ and in some he can convey it away for a valuable consideration without the consent or the sig-

2 In re Burdick (1896) 112 Cal. 387, 44 Pac. 734; Spreckels v. Spreckels (1897) 116 Cal. 339, 48 Pac. 228; Estate of Moffitt (1908) 153 Cal. 359, 95 Pac. 653, 1025; Spreckels v. Spreckels (1916) 172 Cal. 775, 158 Pac. 537; Dargie v. Patterson (1917) $176 \mathrm{Cal}$ 714, 169 Pac. 360; Estate of Dargie (1918) 179 Cal. 418, 177 Pac. 165; Roberts v. Wehmeyer (1923) 66 Cal. Dec. 177, 218 Pac. 22.

${ }^{3}$ It is claimed that our court adopted the doctrine from the Spanish law from which our community property came. See Roberts v. Wehmeyer, supra, n. 2.

4 Stats. 1917, p. 829.

${ }^{5}$ Sec. 172, Civil Code of California; Sec. 4622, Revised Statutes of Texas; Sec. 3850, Civil Code of Arizona; Sec. 4666, Compiled Statutes of Idaho, 1919; Sec. 2404, Revised Civil Code of Louisiana; Sec. 2766, New Mexico Code of 1915; Sec. 2160, Revised Laws of Nevada; Sec. 5917, General Statutes of Washington.

- Sec. 172a, Civil Code of California; Sec. 4622, Revised Statutes of Texas; Sec. 3850, Civil Code of Arizona; Sec. 4666 Compiled Statutes of Idaho, 1919; Sec. 2404, Revised Civil Code of Louisiana; Sec. 2766, New Mexico Code of 1915; Sec. 2160, Revised Laws of Nevada; Sec. 5918, General Statutes of Washington. 
nature of the wife, ${ }^{7}$ a right he has not possessed in this state since 1917. Here is an instance where, in fact, the husband has less power in California. In some of the other states the wife has testamentary capacity over one-half of the property in case she predeceases her husband. ${ }^{8}$ Now even this power has been accorded her in California by the 1923 amendment to Section 1401 of the Civil Code. ${ }^{9}$ (It is fair to note that the Treasury Decisions above mentioned were made prior to 1923.).

This brief analysis would seem to show that there is no practical justification for a ruling which does not give to husbands and wives in California the same benefits as regards Federal income and estate taxes as are given to the spouses in the other states which have the community property system.

It is believed that no relief can be had unless and until our own Supreme Court sees fit to hold that the wife now has a vested interest in the community property. It is suggested that Section 172a, which was added to the Civil Code in 1917, should be given this effect. Federal Judge Rudkin so decided in Blum v. Wardell, ${ }^{10}$ in which case he held that in computing the Federal estate tax the one-half of the community property to which the wife succeeded in California should not be included in the gross estate. The United States Circuit Court of Appeals, Judge Hunt dissenting, affirmed this decision, II but on another ground, the court being of the opinion that because the wife's one-half is specifically made exempt from the state inheritance tax, it should also be exempt from the Federal estate tax. Subsequently the United States Supreme Court denied a petition for a writ of certiorari, ${ }^{12}$ and recently the motion of the United States before the Supreme Court to revoke this order denying a writ of certiorari was withdrawn. ${ }^{13}$ However, it is understood the government does not accept the decision as final, and still takes the position that in California all the community property should be included in the gross estate in computing the tax.

With due deference to the District Court's opinion in Blum v.

${ }^{7}$ Sec. 4622, Revised Statutes of Texas; Sec. 2404, Revised Civil Code of Louisiana; Sec. 2766, New Mexico Code of 1915; Sec. 2160, Revised Laws of Nevada.

${ }^{8}$ Sec. 1100 , Civil Code of Arizona; Sec. 7803, Compiled Statutes of Idaho, 1919; Secs. 915 and 916, Revised Civil Code of Louisiana; Sec. 1342, General Statutes of Washington.

S Stats. 1923, p. 29.

10 (1920) 270 Fed. 309.

11 (1921) 276 Fed. 226.

12 (1922) 258 U. S. 617, 66 L. Ed. 793, 42 Sup. Ct. Rep. 271.

13 Oct. 22, 1923. 
Wardell, it is not reasonable to assume that our Supreme Court will hold that since the 1917 amendment the wife has a vested interest in community property. The rule that the wife's right is merely in the nature of an expectancy, like that of an heir, has become deeply imbedded in the state's jurisprudence as a rule of property, and the 1917 amendment, providing as it does merely for the wife's signature on conveyances, mortgages and leases of community real property, hardly manifests an intention on the part of the legislature to disturb the existing rule as to the nature of the wife's interest. ${ }^{14}$ The big war years of 1917 and 1918, when incomes were large and surtaxes were high, are at stake, but the chances of a refund to those in California who are affected would seem very slim indeed.

There is far more ground for holding, however, that with the 1923 amendment to Section 1401 of the Civil Code, ${ }^{15}$ granting to the wife testamentary disposition over one-half of the community property in case she predeceases her husband, there has come a change, and that now the wife has a vested interest in one-half of the community property, if she never did before. Under the well-known rule in this state, this would apply only to community property earned or acquired after the act went into effect, not including property acquired after the act with the proceeds of other community property acquired before. ${ }^{16}$ A wife in this state has now substantially all the rights as to community property enjoyed by those of her sex and position in each of the other community property states, and more rights than are possessed by wives in some of the other states. ${ }^{17}$ The fact that the husband still has the management of the community property is of no consequence, as it may be considered that this power is given to him simply as the agent for the commu-

14 In Spreckels v. Spreckels (1916) 172 Cal. 775, 158 Pac. 537, the Supreme Court used the following language in speaking of the 1891 Ameudment to Sec. 172 of the Civil Code (p. 782): "Neither does the proviso purport to vest in the wife, during the marriage, any present interest or estate in the community property given away by the husband without her written consent. In view of the long settled doctrine that the entire estate therein is in the husband during the marriage relation, a doctrine that had become a fixed and well understood rule of property, it is not to be supposed that the legislature would have made a change of so radical a character without plain language to that effect. We do not find in the proviso such language, nor anything that can reasonably be so construed. If it confers upon her, during the marriage, any right respecting such gifts, it is nothing more than a right to revoke the gift and, if necessary, sue to recover the property, not as her separate estate, but to reinstate it as a part of the community property with the title vested in the husband and subject to sale by him, as before."

15 Supra, n. 9.

16 Roberts v. Wehmeyer, supra, n. 2.

17 Supra, n. 7. 
nity. Such has been the uniform ruling in the other community property states. ${ }^{18}$

The United States Treasury Department has so far, however, refused to concede that even under the 1923 act husband and wife domiciled in California may each report one-half of the community income (received after the passage of the act) and the matter will have to be fought out in the courts. A decision from our own Supreme Court being first necessary, the point may not be passed on for several years to come. In the meantime, taxpayers in California who are affected will have to pay their income tax under protest (that is the only safe way) ${ }^{19}$ and then file a claim for refund within the statutory period. ${ }^{20}$

Mr. Mellon has recommended in his report on taxation that Congress abolish this right of the husband and wife in community property states to split the community income for the purpose of income tax. Can this be done without violating any constitutional rights? It is felt that such spouses enjoy an unwarranted advantage over those in the other states of the Union where the community property

18 Warburton v. White, supra, n. 1; Arnett v. Reade, supra, n. 1; Holyoke v. Jackson, supra, n. 1; In re Williams' Estate, supra, n. 1; Beals v. Ares, supra, n. $1 ;$ La Tourette v. La Tourette, supra, n. 1; Kohny v. Dunbar, supra, n. 1; Scott v. Scott, supra, n. 1.

19 Cheeseborough v. United States (1904) 192 U. S. 253, 48 L. Ed. 432, 24 Sup. Ct. Rep. 262; United States v. New York \& Cuba Mail Steamship Co. (1906), 200 U. S. 488, 50 L. Ed. 569, 26 Sup. Ct. Rep., 327; Christio Street Commission Co. v. United States (1903) 126 Fed. 991; Newhall v. Jordan (1908) 160 Fed. 661 ; Bur v. Moffatt (1912) 192 Fed. 984; Mirch v. Treat (1913) 202 Fed. 133; Fox v. Edwards (1923) 287 Fed. 669 . But protest is sometimes held unnecessary where Congress has passed a statute authorizing the refund of taxes illegally assessed and collected. See United States v. Hooslef (1915) 237 U. S. 1, 59 L. Ed. 813, 35 Sup. Ct. Rep. 459; Rand v. United States (1919) 249 U. S. 503, 63 L. Ed. 731, 39 Sup. Ct Rep. 359; Greenport Basin \& Construction Co. v. United States (1920) 269 Fed. 58.

20 Under Sec. 252 of the Revenue Act of 1921, as amended in 1923, a claim for credit or refund of income, war profits or excess profits tax must be presented to the Commissioner of Internal Revenue before the expiration of five years from the date when the return was due or before the expiration of two years from the time the tax was paid. Under Sec. 1316 of the Revenue Act of 1921, amending Sec. 3228 U. S. Revised Statutes, a claim for credit or refund of any other internal revenue tax must be presented to the Commissioner of Internal Revenue within four years next after payment of the tax. This latter section would apply to a claim for refund of Federal estate tax. A claim for refund must first be made before suit can be maintained for the recovery of the tax. Sec. 1318 of the Revenue Act of 1921, amending Sec. 3226 U. S. Revised Statutes; Rock Island A. \& L. R. Co. v. United States (1920) 254 U. S. 141, 65 L. Ed. 188, 41 Sup. Ct. Rep. 55 . Suit must be brought within five years after the payment of the tax or within two years after the disallowance by the Commissioner of the claim for refund or credit, under said Sec. 1318 of the Revenue Act of 1921 as amended in 1923. 
system does not exist. It may be, therefore, that any possible rights of the spouses living in California may be taken away before the present controversy can be heard on its merits.

Esmond Schapiro.

San Francisco, California. 